\title{
Bleaching optimization of tuna (Thunnus sp.) oil using response surface methodology
}

\author{
*Suseno, S.H., Jacoeb, A.M., Nugraha, R. and Salia \\ Department of Aquatic Product Technology, Faculty of Fisheries and Marine Sciences, Bogor Agricultural \\ University, Bogor 16680, Indonesia.
}

\section{Article history:}

Received: 6 February 2021

Received in revised form: 16 March 2021

Accepted: 16 May 2021

Available Online: 28

November 2021

\section{Keywords:}

Adsorbent,

Bleaching,

Response Surface

Methodology,

Tuna oil

\section{DOI:}

https://doi.org/10.26656/fr.2017.5(6).099

\begin{abstract}
The quality of crude tuna (Thunnus sp.) oil aimed for food-sector-purpose can be improved by performing purification. The present study was aimed to optimize the bleaching step during the purification process and determine the optimum variable conditions using response surface methodology (RSM) in obtaining the lowest oxidation parameters value to meet the International Fish Oil Standard (IFOS) standard. A total of five responses including free fatty acids (FFA) value, acid value (AV), peroxide value $(\mathrm{PV})$, anisidine value $(\mathrm{AnV})$ and total oxidation (Totox) value were studied using central composite design (CCD), a full factorial design with all combinations of the factors at two levels (high, +1 , and low, -1 level), repeated thrice; applied for two variable factors (adsorbent concentration [A];\% and adsorption time [B]; mins). The optimum model suggested by the program was a quadratic model for FFA and AnV, and a linear model for $\mathrm{AV}, \mathrm{PV}$ and Totox value. The optimum response was reached by the combination of $5 \%$ adsorbent concentration [A] with adsorption time [B] of 20 mins. This formula reduced the FFA value, AV, PV, AnV, and Totox Value up to $56.57 \%, 55.36 \%, 88.86 \%, 69.69 \%$ and $77.03 \%$, respectively. The purified tuna oil has a clear yellow colour appearance with a rising percentage of pure fish oil for EPA and DHA of $10.71 \%$ and $11.50 \%$ from crude tuna fish oil.
\end{abstract}

\section{Introduction}

Import value of fish oil in Indonesia from 2015 to 2017 rise as much as $13.19 \mathrm{M}, 15.58 \mathrm{M}$, and $18.77 \mathrm{M}$ USD, respectively (MMAF, 2018). This rising demand encourages the local producers in providing quality fish oil products. The abundant volume of crude fish oil (found in by-product form) in Indonesia are not optimally used due to its poor quality. Several strategies have been performed to improve the quality of fish oils in accordance with the industrial standard (Prinyawiwatkul, 2004; Tambunan et al., 2013; Budiadnyani et al., 2015; Hulu et al., 2017; Sathivel and Kamini, 2017).

Crude fish oil can be transformed into quality fish oil throughout several purification steps namely degumming, neutralization, and bleaching (Crexi et al., 2009). The bleaching process is usually completed through adsorption using adsorbent agents such as zeolite, bentonite, active carbon, magnesol XL, etc. The use of $15 \%$ zeolite on crude tuna oil bleaching reduces peroxide value (PV) of $66.93 \%$ and free fatty acid (FFA) value by $60 \%$ (Budiadnyani, 2017). Application of $5 \%$ magnesol $\mathrm{XL}$ at temperature of $50^{\circ} \mathrm{C}$ for 20 mins on sardine crude oil decreases FFA value, PV, anisidine value $(\mathrm{AnV})$ and Totox value up to $98.40 \%, 98.49 \%$, $76,58 \%$, and $79,31 \%$, respectively (Hulu et al., 2017).

The bleaching process is affected by at least two factors such as the adsorbent concentration and adsorption time. Determination of optimum point for these factors has an important role to gain optimum response of each variable (Setyawati et al., 2015). One of the simple yet precise methods to establish the optimum points of every factor is response surface methodology (RSM).

The present study aimed to optimize the bleaching process of crude tuna oil to gain optimum adsorbent concentration [A] and adsorption time [B] using response surface methodology (RSM) in providing quality purified oil according to the allowable standard set by the International Fish Oil Standard (IFOS). Oxidation parameters of fish oil according to Codex (2017) include Acid value $\leq 3 \mathrm{mg} \mathrm{KOH} / \mathrm{g}$, Peroxide 
value $\leq 5$ milliequivalents of active oxygen $/ \mathrm{kg}$ oil, Anisidine Value, $\leq 20$ milliequivalent of active oxygen/ $\mathrm{kg}$ oil, Total oxidation (Totox) $\leq 26$ milliequivalents of active oxygen $/ \mathrm{kg}$ oil.

\section{Materials and methods}

\subsection{Materials}

The main material used was crude tuna (Thunnus sp.) oil which was obtained in the form of canned-byproducts oil from PT. Bali Maya industry. The initial sample was kept at room temperature $\left(25^{\circ} \mathrm{C}\right)$ during transport from Bali to Bogor and then stored in the laboratory freezer until analysis was performed.

\subsection{Methods}

The crude oil was characterized for its fatty acid profiles and oxidation properties including free fatty acid, acid value, peroxide value, $\mathrm{p}$-anisidine value and total oxidation value prior to the purification process with three main steps namely degumming, neutralization and bleaching.

\subsubsection{Two-step degumming}

There are two steps of degumming processes applied in this study. The first degumming process was performed by adding $5 \%(\mathrm{v} / \mathrm{v}) \mathrm{H}_{2} \mathrm{O}$ to the crude oil, stirring it by using a magnetic stirrer at $50^{\circ} \mathrm{C}$ for 20 mins before centrifuging $(10000 \mathrm{rpm})$ it at $10^{\circ} \mathrm{C}$ for $10 \mathrm{mins}$. The second one was performed by adding a $5 \%(\mathrm{w} / \mathrm{v})$ $\mathrm{NaCl}$ in a $1: 1(\mathrm{v} / \mathrm{v})$ ratio, stirred at $50^{\circ} \mathrm{C}$ for 10 mins and subjected to centrifugation at $10^{\circ} \mathrm{C}$ for 10 mins.

\subsubsection{Neutralizing}

The liquid fraction obtained from the second degumming process was then neutralized by adding sodium hydroxide $(\mathrm{NaOH})$ to the same amount of free fatty acid content. As for the present study, the amount of sodium hydroxide added was $16^{\circ} \mathrm{Be}$ with an excess value of 0.20 (Hodgum, 1995). The sample was subjected to magnetic stirring at $50^{\circ} \mathrm{C}$ for 10 mins and was centrifuged.

\subsubsection{Bleaching optimization using response surface method (RSM)}

Bleaching optimization was aimed to find the precise adsorbent concentration $[\mathrm{A}]$ and adsorption time [B] in order to gain the optimum bleaching process. The ranges of adsorbent concentration [A] and adsorption time [B] were determined according to a previous study (Nurnafisah, 2016) prior to the validation process. The optimum bleaching condition was obtained by purification using Magnesol XL. The optimization was conducted on the basis of oxidation parameter values. These values should be in accordance with the standard of commercial fish oil.

The validation of the RSM model was obtained by comparing the predicted to the actual data. Response surface methodology (RSM) is a group of the mathematic-statistical technique used to model and analyse a problem where the response is affected by some variables, in order to optimize that response (Montgomery, 2005). The RSM offers an easier way to determine the optimum condition of a process, avoid ineffective (repeated trial) and inefficient (high cost and time) experiments.

Determination of optimum processes by RSM involved some analysis including model determination, analysis of variance (ANOVA) and the response of surface. There are several polynomial models applied on RSM namely linear, quadratic and cubical models (Puspitojati and Santoso, 2012). Each response results in a model fit to the analysis result. The best model obtained is determined according to some parameters, significant $(p<0.05)$ SMSS (sequential model of sum square), insignificant $(p>0.05)$ Lack of fit, PRESS (prediction residual error of sum square) in the lowest value, $R^{2}$ (coefficient) $>75 \%$ and the lowest (or close to that $R^{2}$ value) gap between $R^{2}$ and adjusted- $R^{2}$ value.

Insignificant $(\mathrm{p}>0.05)$ lack of fit value indicates the fitness of the model or the model is already representing the data (Nadjib, 2016). PRESS value indicates the data's fault. The $\mathrm{R}^{2}$ value shows the effect of factor toward response, where the higher (close to 1 ) $R^{2}$ value the more significant effect obtained from factor to response. Meanwhile, the adjusted- $\mathrm{R}^{2}$ value indicates the suitability of gained $R^{2}$ value, the lower the value gap between $R^{2}$ and adjusted- $R^{2}$ the better $R^{2}$ resulted (Nadjib, 2016). The central composite design (CCD) of the trial is determined as depicted in Table 3.

\subsection{Analysis procedures}

Oxidation parameters of the sample were analysed according to AOCS procedures including Free Fatty Acid (FFA) (AOCS, 2017a), Acid Value (AV), Peroxide Value (PV) (AOCS, 1996), anisidine value and Totox Value (AOCS, 2017b). Fatty acid profile analysis was also performed in this study (AOAC, 2005).

\subsection{Data analysis by using RSM}

The experimental design used to optimize the bleaching process of crude tuna oil was central composite design (CCD) from RSM which was analysed using Design Expert 12. The CCD used 5 levels of $-\alpha-1$ (low), $0+1$ (high)and $+\alpha$. Variables and experiment 
design levels used in this study are shown in Table 1 as referring to the previous study (Nurnafisah, 2016).

Response variables used in this study include FFA, $\mathrm{AV}, \mathrm{PV}, \mathrm{AnV}$ and Totox values. Experimental design and response for each treatment are shown in Table 2 . The obtained data from the laboratory (actual data) were fitted to the linear, quadratic, and interaction models which were expressed in the following equation:

$$
Y=\beta_{0}+\sum_{i=1}^{3} \beta_{i} X_{i}+\sum_{i=1}^{3} \beta_{i i} X_{i}^{2}+\sum_{i} \sum_{j} \beta_{i j} X_{i} X_{j}+\varepsilon_{i j}
$$

Where $Y$ represents the predicted response, $\beta_{0} \beta_{0}$ is the constant, $X_{\mathrm{ij}}$ is the variable (adsorbent concentration and time), $\beta_{\mathrm{i}} \beta_{\mathrm{i}}$ is a linear coefficient, $\beta_{\mathrm{ij}} \beta_{\mathrm{ij}}$ is interaction coefficient, $\beta_{\mathrm{ii}} \beta_{\mathrm{ii}}$ is quadratic coefficient, and $\varepsilon_{\mathrm{ij}} \varepsilon_{\mathrm{ij}}$ is error.

\section{Results and discussion}

\subsection{Characterization of crude tuna oil}

The crude tuna oil has a blackish brown colour appearance and fishy odour (Figure 1). Dissolved pigments in fish oil can degrade and change colour from yellow to brownish (Suparno and Muchlis, 2013). This degradation is caused by several factors such as heating temperature (Syakiroh, 2012) and impurities in the form of phosphatide (Estiasih, 2009), proteins and pigments (Wardhani, 2012). The initial profile of crude tuna oil quality can be seen in Table 2 .

The results showed that the sample was of poor quality indicated by the high PV, AnV Totox value (over allowed standard). The presence of eicosapentaenoic acid (EPA) and docosahexaenoic acid (DHA) in fish oil accelerates the oxidation caused by peroxide compounds formed when reacted with oxygen (Ahmadi and Mushollaeni, 2007). Further decomposition of this compound triggers the rise of anisidine value $(\mathrm{AnV})$, which is mainly influenced by oxygen, heat or light (Kusnandar, 2010) and storage time (Zuta et al., 2007; Feryana et al., 2014; Huli et al., 2014).

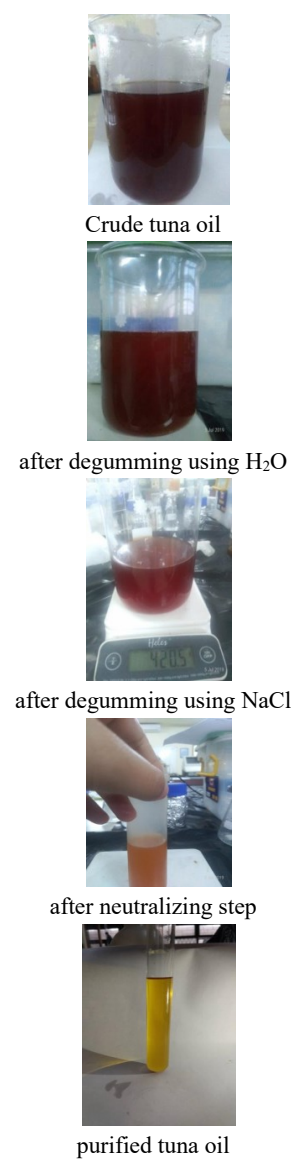

Figure 1. Appearance transformation of tuna (Thunnus sp.) oil during the purification process

\subsection{Crude tuna oil purification}

The crude fish oil obtained as by-product activities is having a poor quality (Sari et al., 2015) caused by impurities such as phosphatide, protein, pigment, in addition to free fatty acid and peroxide value (Wardhani, 2012). Removal of non-oil fraction through purification process including degumming, neutralizing and bleaching should be carried out to obtain high standard fish oil (Crexi et al., 2009).

The degumming step is aimed to remove gum (in the form of slime or sap) and some dirt such as phospholipid, protein, carbohydrate, water and resin (Ketaren, 2012). In this study, the degumming process was performed using $\mathrm{H}_{2} \mathrm{O}$ and $\mathrm{NaCl}$, respectively, in

Table 1. Variables and experiment design levels

\begin{tabular}{lcccccc}
\hline \multirow{2}{*}{ Factor } & \multirow{2}{*}{ Code } & \multicolumn{5}{c}{ Level } \\
\cline { 3 - 7 } & & $-\left(2^{2}\right)^{1 / 4}$ & -1 & 0 & 1 & $+\left(2^{2}\right)^{1 / 4}$ \\
\hline Adsorbent concentration (\%) & $\mathrm{X}_{1}$ & 0.17 & 1 & 3 & 5 & 5.83 \\
Adsorption time (mins) & $\mathrm{X}_{2}$ & 7.93 & 10 & 15 & 20 & 22.1 \\
\hline
\end{tabular}

Table 2. Oxidation properties of crude tuna (Thunnus sp.) oil

\begin{tabular}{cccc}
\hline Parameters & Obtained value & Allowed Standard [20] & Eligibility \\
\hline FFA (\%) & $0.99 \pm 0.01$ & $\leq 1.5$ & Allowed \\
AV $(\mathrm{mg} \mathrm{KOH} / \mathrm{g})$ & $1.68 \pm 0.002$ & $\leq 3$ & Allowed \\
PV $(\mathrm{meq} / \mathrm{kg})$ & $14.54 \pm 0.02$ & $\leq 5$ & Not allowed \\
AnV $(\mathrm{meq} / \mathrm{kg})$ & $46.81 \pm 0.24$ & $\leq 20$ & Not allowed \\
Totox $(\mathrm{meq} / \mathrm{kg})$ & $75.89 \pm 0.28$ & $\leq 26$ & Not allowed \\
\hline
\end{tabular}


order to separate hydratable phosphatide and transform non-hydratable phosphatide into hydratable one (Ristianingsih et al., 2011). The $\mathrm{NaCl}$ solution is also used to bind protein compounds and, at the same time, able to hydrate water from oil which affects the quality of fish oil (Ketaren, 2012). A higher concentration of salt solution decreases protein solubility and precipitates it.

Neutralization using alkali is aimed to remove FFA, oxidation product and phospholipid as an excess product from the degumming process (Ketaren, 2012). In this process, FFA is separated from the oil by reacting FFA with alkali to form soap stock. Sapon and the unsaponified fraction is then separated so that the FFA value in the product decreased (Estiasih, 2009).

The last step was bleaching in the form of physical purification through adsorbent (magnesol XL) addition. The pigment in oil is adsorbed through the adsorbent surface, along with colloid suspension (resin and gum), and other products from oil degradation such as peroxide (Ketaren, 2012). Magnesol XL is a synthetic adsorbent composed of magnesium silica with a porous structure to adsorb dirt in oil. Magnesol XL is able to decrease pigment compound, FFA and other dirt found in fish oil (Suseno et al., 2012), in addition to its ability to decrease peroxide value (Suseno et al., 2013).

After purification, the colour appearance of tuna fish oil was changed from blackish brown to a clear yellow. The pigment colour has decreased during the purification process. Bleaching using adsorbent (magnesol XL) removes the pigment colour by adsorbing dirt compound that improves the colour appearance of oil (Dari et al., 2017). Purification of fish oil improves its quality (Suseno et al., 2016).

\subsection{Bleaching optimization on oxidation properties of tuna oil by response surface methodology (RSM)}

The central composite design (CCD) of the trial is determined as depicted in Table 3. Optimization of tuna
(Thunnus sp.) oil purification was aimed to minimize all studied oxidation parameters (response). According to the table, FFA value ranged from 0.36 to $0.82 \%$, AV from 0.66 to $1.39 \mathrm{mg} \mathrm{KOH} / \mathrm{g}$, PV from 1.49 to $7.2 \mathrm{meq} /$ $\mathrm{kg}$, AnV from 14.11 to $35.33 \mathrm{meq} / \mathrm{kg}$, and Totox value from 17.08 to $49.72 \mathrm{meq} / \mathrm{kg}$

\subsubsection{Analysis for free fatty acid (FFA) value of tuna oil}

The quadratic model is the model summary suggested for the FFA value. Determination of the model was based on the sequential model of sum square (SMSS) value of 0.0060 which was significant $(p<0.05)$. The lack of fit value of 0.2251 was not significant $(p>0.05)$ indicated the fitness of the model. The $\mathrm{R}^{2}$ value of 0.988 indicated a $98.8 \%$ of combination effect of factors $[\mathrm{A}]$ and $[\mathrm{B}]$ towards response. The fitness of the $\mathrm{R}^{2}$ value can be seen from a closer adjusted- $\mathrm{R}^{2}$ value of 0.996 or $99.6 \%$. The summary model of FFA response and its analysis of variance are shown in Table 4.

The analysis of variance (ANOVA $\alpha=0.05$ ) result shows that both linear and quadratic effects of factor [A] had given a significant $(\mathrm{p}<0.05)$ effect towards response with probability value of 0.0001 and 0.0024 , respectively. The best-fitted equation of FFA response was given as follows:

\section{$\mathrm{Y}=0.776338-0.0036278 \mathrm{~A}+0.005510 \mathrm{~B}-0.001 \mathrm{AB}-$ $0.005518 \mathrm{~A}^{2}-0.000064 \mathrm{~B}^{2}$}

According to the given equation above it is known that the linear effect of concentration, the interaction between concentration [A] and time [B], quadratic concentration and time result in a positive effect in minimizing FFA value response, meanwhile, the effect of concentration and time interaction, along with quadratic time, remained insignificant.

FFA is a derivate product of triacyl-glyceride hydrolysis which is lead to free fatty acid and glycerol

Table 3. Central composite design (CCD) of crude tuna (Thunnus sp.) oil purification using RSM

\begin{tabular}{cccccccc}
\hline \multirow{2}{*}{ Run } & \multicolumn{2}{c}{ Coded variables } & \multicolumn{5}{c}{ Response (Y) } \\
\cline { 2 - 8 } & A & B & FFA & AV & PV & AnV & Totox \\
\hline 1 & 0 & 1.414 & $0.63 \pm 0.01$ & $1.07 \pm 0.03$ & $3.36 \pm 0.05$ & $22.90 \pm 0.11$ & $29.65 \pm 0.05$ \\
2 & -1 & 1 & $0.80 \pm 0.002$ & $1.37 \pm 0.01$ & $4.99 \pm 0.02$ & $31.4 \pm 0.14$ & $41.37 \pm 0.17$ \\
3 & 1 & 1 & $0.44 \pm 0.01$ & $0.75 \pm 0.002$ & $1.49 \pm 0.01$ & $14.11 \pm 0.06$ & $17.08 \pm 0.07$ \\
4 & 1.414 & 0 & $0.36 \pm 0.07$ & $0.66 \pm 0.12$ & $1.62 \pm 0.03$ & $18.49 \pm 0.31$ & $21.71 \pm 0.33$ \\
5 & 0 & -1.414 & $0.63 \pm 0.02$ & $1.12 \pm 0.01$ & $4.11 \pm 0.18$ & $27.50 \pm 1.32$ & $35.73 \pm 1.67$ \\
6 & -1.414 & 0 & $0.82 \pm 0.005$ & $1.39 \pm 0.01$ & $7.2 \pm 0.20$ & $35.33 \pm 0.20$ & $49.72 \pm 0.30$ \\
7 & 0 & 0 & $0.64 \pm 0.01$ & $1.09 \pm 0.02$ & $3.49 \pm 0.02$ & $24.48 \pm 0.15$ & $31.45 \pm 0.18$ \\
8 & 0 & 0 & $0.63 \pm 0.005$ & $1.07 \pm 0.01$ & $3.45 \pm 0.03$ & $24.93 \pm 0.11$ & $31.83 \pm 0.05$ \\
9 & 1 & -1 & $0.77 \pm 0.002$ & $0.49 \pm 0.001$ & $2.44 \pm 0.06$ & $18.00 \pm 0.96$ & $22.87 \pm 1.07$ \\
10 & -1 & -1 & $0.78 \pm 0.002$ & $1.34 \pm 0.004$ & $6.05 \pm 0.05$ & $34.12 \pm 0.26$ & $46.21 \pm 0.16$ \\
11 & 0 & 0 & $0.64 \pm 0.002$ & $1.09 \pm 0.003$ & $3.69 \pm 0.19$ & $24.48 \pm 0.02$ & $31.86 \pm 0.40$ \\
\hline
\end{tabular}

$\mathrm{A}=$ adsorbent (\%), B = time (mins), FFA (\%), AV (mg KOH/g), PV (meq/kg), AnV (meq/kg), and Totox (meq/kg) 
Table 4. Analysis of variance (ANOVA) for quadratic model of FFA value of tuna oil

\begin{tabular}{ccccccc}
\hline Source & Sum of Squares & Df & Mean Square & F Value & Prob $>$ F & \\
\hline Model & 0.2313 & 5 & 0.0463 & 542.26 & $<0.0001$ & Significant \\
A & 0.228 & 1 & 0.228 & 2672.91 & $<0.0001$ & \\
B & $1.57 \mathrm{E}-10$ & 1 & $1.57 \mathrm{E}-10$ & $1.85 \mathrm{E}-06$ & 0.999 & \\
$\mathrm{AB}$ & 0.0004 & 1 & 0.0004 & 4.69 & 0.0826 & \\
$\mathrm{~A}^{2}$ & 0.0028 & 1 & 0.0028 & 32.29 & 0.0024 & \\
$\mathrm{~B}^{2}$ & 0 & 1 & 0 & 0.2911 & 0.6127 & \\
Residual & 0.0004 & 5 & 0.0001 & & & \\
Lack of Fit & 0.0004 & 3 & 0.0001 & 3.6 & 0.2251 & Not significant \\
Pure Error & 0.0001 & 2 & 0 & & & \\
Cor Total & 0.2317 & 10 & & &
\end{tabular}

formation (Panagan et al., 2011). The FFA value found in the fish oil sample is strongly related to the alkali amount applied during purification (Sathivel and Prinyawiwatkul, 2004).

\subsubsection{Analysis for acid value (AV) of tuna oil}

The AV values were best fitted into a linear model with a $p$-value of 0.0001 which was significant $(p<0.05)$. The lack of fit value of 0.0705 was not significant $(p>0.05)$ indicated the fitness of the model. The $\mathrm{R}^{2}$ value of 0.9616 indicated a $96.16 \%$ of combination effect of factors $[\mathrm{A}]$ and $[\mathrm{B}]$ towards response. The fitness of the $\mathrm{R}^{2}$ value can be seen from a closer adjusted- $\mathrm{R}^{2}$ value of 0.9780 or $97.80 \%$. The summary model of AV response and its analysis of variance are shown in Table 5.

Acid value (AV) has a positive correlation with FFA value. The oxidized fish oil is prone to rancidity since the break of triacyl-glyceride into acid value and glycerol raised acid value number (Mohanarangan, 2012). The analysis of variance (ANOVA $\alpha=0.05$ ) result shows that the linear model of factor $[\mathrm{A}]$ had given a significant $(p<0.05)$ effect towards response with a probability value of 0.0001 . The best explanatory model equation to optimize AV response was given as follows:

$$
\mathrm{Y}=1.50474-0.138857 \mathrm{~A}-0.001514 \mathrm{~B}
$$

According to the given equation above it is known that the linear effect of concentration $[\mathrm{A}]$ and time [B] result in a positive effect in minimizing AV response, however, the linear effect of time [B] remained insignificant.

\subsubsection{Analysis for peroxide value (PV) of tuna oil}

The quadratic model is the model summary suggested for the PV value. Determination of the model was based on an SMSS value of 0.0001 which was significant $(p<0.05)$ towards response. The lack of fit value of 0.0812 was not significant $(p>0.05)$ indicated the fitness of the model. The $\mathrm{R}^{2}$ value of 0.9191 indicated a $91.91 \%$ of combination effect of factors [A] and [B] towards response, while the rest $8.09 \%$ was affected by other unidentified causes. The fitness of the $\mathrm{R}^{2}$ value can be seen from a closer adjusted- $\mathrm{R}^{2}$ value of 0.9513 or $95.13 \%$. The summary model of PV response and its analysis of variance are shown in Table 6.

Peroxide value is a number of peroxides (stated in milliequivalent active oxygen) contained in a $1.000 \mathrm{~g}$ of compound (Suseno et al., 2013). Peroxide can be caused by the interaction between the double bond of fish oil and oxygen. The higher PV of oil, the higher its deterioration (Ketaren, 2012) and rancidity level (Khotimah et al., 2013). The oxidative compound is free radical lead to several degenerative diseases such as cancer, Alzheimer, cardiac-related disease, kidney failure and fibrosis (Sarma et al., 2010). Peroxide is a starter product from a labile oxidation reaction and continually reacts in the presence of oxygen and other triggers (Hulu

Table 5. Analysis of variance (ANOVA) for AV of tuna oil

\begin{tabular}{ccccccc}
\hline Source & Sum of Squares & Df & Mean Square & F Value & Prob $>$ F & \\
\hline Model & 0.6178 & 2 & 0.3089 & 223.26 & $<0.0001$ & significant \\
A & 0.6173 & 1 & 0.6173 & 446.2 & $<0.0001$ & \\
B & 0.0005 & 1 & 0.0005 & 0.3319 & 0.5804 & \\
Residual & 0.0111 & 8 & 0.0014 & & & \\
Lack of Fit & 0.0108 & 6 & 0.0018 & 13.5 & 0.0705 & not significant \\
Pure Error & 0.0003 & 2 & 0.0001 & & & \\
Cor Total & 0.6289 & 10 & & & & \\
\hline A = adsorbent concentration $(\%), B=$ adsorption time (mins)
\end{tabular}


Table 6. Analysis of variance (ANOVA) for PV of tuna oil

\begin{tabular}{ccccccc}
\hline Source & Sum of Squares & Df & Mean Square & F Value & Prob $>F$ & \\
\hline Model & 29.31 & 2 & 14.65 & 98.73 & $<0.0001$ & significant \\
A & 28.13 & 1 & 28.13 & 189.53 & $<0.0001$ & \\
B & 1.18 & 1 & 1.18 & 7.94 & 0.0226 & \\
Residual & 1.19 & 8 & 0.1484 & & & \\
Lack of Fit & 1.15 & 6 & 0.1924 & 11.64 & 0.0812 & not significant \\
Pure Error & 0.0331 & 2 & 0.0165 & & & \\
Cor Total & 30.5 & 10 & & & & \\
\hline A = adsorbent concentration (\%), B = adsorption time (mins) &
\end{tabular}

et al., 2017). The analysis of variance (ANOVA $\alpha=$ 0.05 ) result shows that the linear model of factor $[\mathrm{A}]$ had given a significant $(\mathrm{p}<0.05)$ effect towards $\mathrm{PV}$ response with a probability value of 0.0001 and 0.0226 . The best explanatory model equation to optimize PV response was given as follows:

$$
\mathrm{Y}=7.77057-0.937335 \mathrm{~A}-0.076678 \mathrm{~B}
$$

According to the given equation above it is known that the linear effect of concentration [A] and time [B] result in a positive effect in minimizing PV response. Figure 2 shows the 3D response surface graph of the regression coefficient, which represents the effect of these factors on PV response.

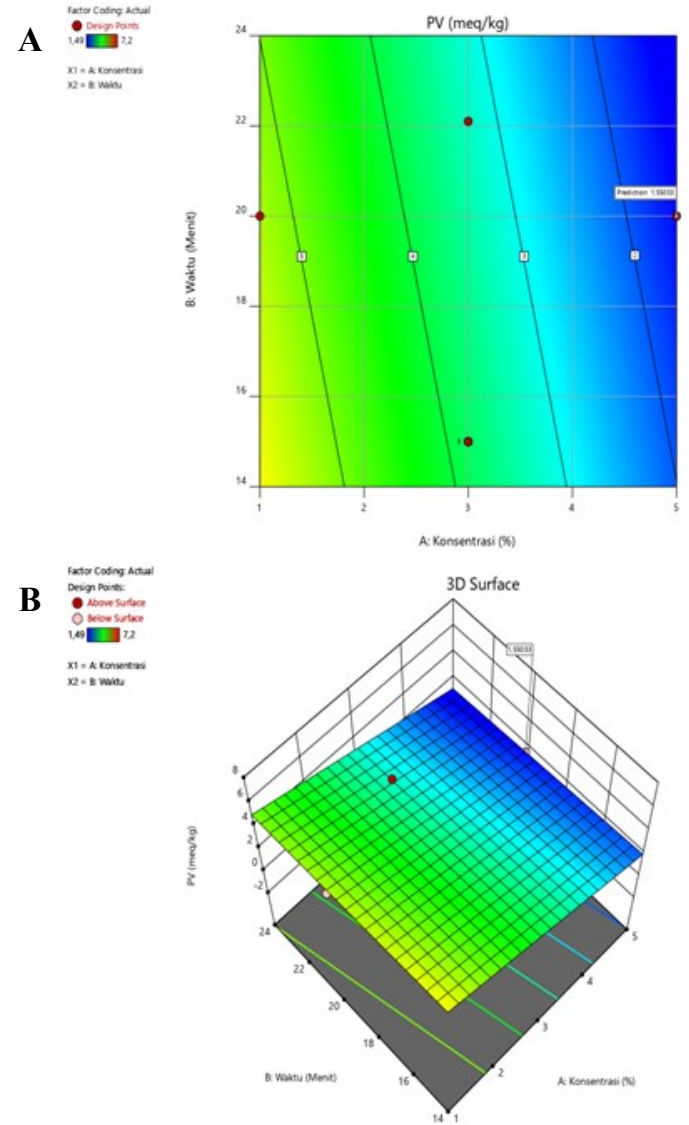

Figure 2. Response surface graph for PV (meq $/ \mathrm{kg}$ ) as function of adsorbent concentration [A] and adsorption time [B]

\subsubsection{Analysis for anisidine value (AnV) of tuna oil}

The quadratic model is the model summary suggested for the AnV. Determination of the model was based on the SMSS value of 0.0060 which was significant $(p<0.05)$ towards response. The lack of fit value of 0.9653 was not significant $(p>0.05)$ indicated the fitness of the model. The $\mathrm{R}^{2}$ value of 0.9991 indicated a $99.91 \%$ of combination effect of factors [A] and [B] towards response, while the rest $0.9 \%$ was affected by other unidentified causes. The fitness of the $\mathrm{R}^{2}$ value can be seen from a closer adjusted- $\mathrm{R}^{2}$ value of 0.9992 or $99.92 \%$ (Table 7).

Anisidine value is a derivative compound of primary oxidation, thus categorized as secondary oxidation parameter on oil products. P-anisidine compound is formed throughout fatty acid breakage along with hydroperoxide conversion to aldehyde and ketone (Ketaren, 2012). The analysis of variance (ANOVA $\alpha=$ $0.05)$ result shows that linear model of factor $[A]$, linear model of factor $[\mathrm{B}]$, interaction between $[\mathrm{A}]$ and $[\mathrm{B}]$, quadratic model of factor $[\mathrm{A}]$, and quadratic model of factor $[\mathrm{B}]$ had given a significant $(\mathrm{p}<0.05)$ effect towards $\mathrm{AnV}$ response with probability value of $0.0001,0.0001$, $0.0352,0.0054$, and 0.0218 . The best explanatory model equation to optimize $\mathrm{AnV}$ response was given as follows:

\section{$\mathrm{Y}=42.19158-2.93069 \mathrm{~A}-0.593555 \mathrm{~B}-0.029250 \mathrm{AB}-$ $0.133453 \mathrm{~A}^{2}+0.011786 \mathrm{~B}^{2}$}

According to the given equation above it is known that linear effect of concentration [A] linear effect of factor $[\mathrm{B}]$, the interaction between $[\mathrm{A}]$ and $[\mathrm{B}]$, the quadratic effect of factor $[\mathrm{A}]$, and the quadratic effect of factor [B] result in a positive effect in minimizing AnV response. Figure 3 shows the 3D response surface graph of the regression coefficient, which represents the effect of these factors on $\mathrm{AnV}$ response.

\subsubsection{Analysis for total oxidation (Totox) value of tuna oil}

The linear model is the model summary suggested for the Totox value. Determination of the model was taken based on the SMSS value of 0.0001 which was significant $(p<0.05)$ towards response. The lack of fit 
Table 7. Analysis of variance (ANOVA) for AnV of tuna (Thunnus sp.) oil

\begin{tabular}{|c|c|c|c|c|c|c|}
\hline Source & Sum of Squares & $\mathrm{Df}$ & Mean Square & F Value & Prob $>F$ & \\
\hline Model & 404.24 & 5 & 80.85 & 2312.31 & $<0.0001$ & significant \\
\hline A & 334 & 1 & 334 & 9552.51 & $<0.0001$ & \\
\hline $\mathrm{B}$ & 21.52 & 1 & 21.52 & 615.61 & $<0.0001$ & \\
\hline $\mathrm{AB}$ & 0.3422 & 1 & 0.3422 & 9.79 & 0.0352 & \\
\hline $\mathrm{A}^{2}$ & 1.05 & 1 & 1.05 & 30.11 & 0.0054 & \\
\hline $\mathrm{B}^{2}$ & 0.466 & 1 & 0.466 & 13.33 & 0.0218 & \\
\hline Residual & 0.1399 & 4 & 0.035 & & & \\
\hline Lack of Fit & 0.0049 & 2 & 0.0024 & 0.036 & 0.9653 & not significant \\
\hline Pure Error & 0.135 & 2 & 0.0675 & & & \\
\hline Cor Total & 404.38 & 9 & & & & \\
\hline \multicolumn{7}{|c|}{$\mathrm{A}=$ adsorbent concentration $(\%), \mathrm{B}=$ adsorption time $(\mathrm{mins})$} \\
\hline \multicolumn{7}{|c|}{ Table 8. Analysis of variance (ANOVA) for Totox value of tuna (Thunnus sp.) oil } \\
\hline Source & Sum of Squares & $\mathrm{Df}$ & Mean Square & F Value & Prob $>F$ & \\
\hline Model & 895.3 & 2 & 447.65 & 1208.91 & $<0.0001$ & Significant \\
\hline A & 849.06 & 1 & 849.06 & 2292.96 & $<0.0001$ & \\
\hline B & 46.19 & 1 & 46.19 & 124.74 & $<0.0001$ & \\
\hline Residual & 2.59 & 7 & 0.3703 & & & \\
\hline Lack of Fit & 2.49 & 5 & 0.4975 & 9.52 & 0.0977 & not significant \\
\hline Pure Error & 0.1045 & 2 & 0.0522 & & & \\
\hline Cor Total & 897.89 & 9 & & & & \\
\hline
\end{tabular}

$\mathrm{A}=$ adsorbent concentration $(\%), \mathrm{B}=$ adsorption time (mins)

A
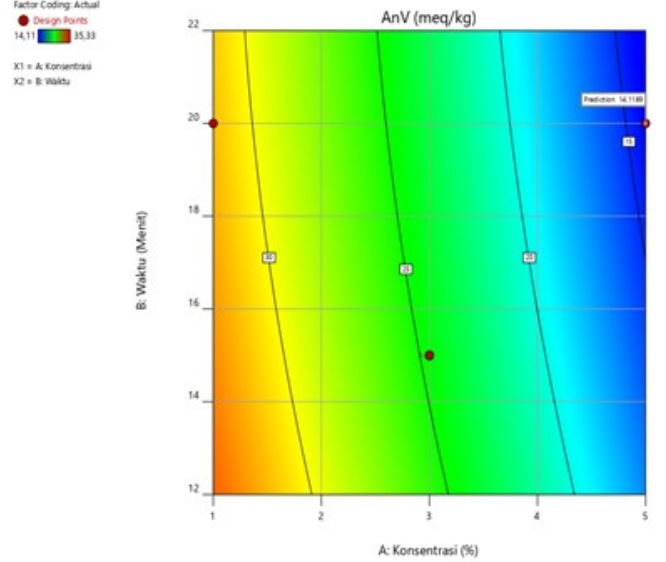

B
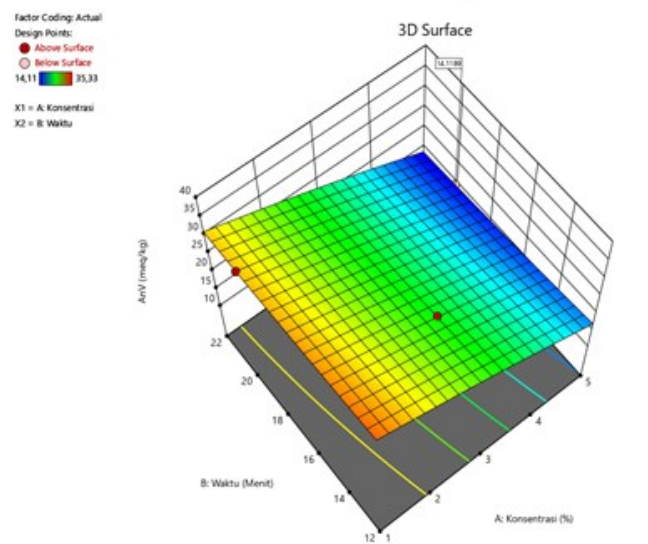

Figure 3. Response surface graph for $\mathrm{AnV}$ (meq $/ \mathrm{kg}$ ) as function of adsorbent concentration [A] and adsorption time [B]

value of 0.0977 was not significant $(p>0.05)$ indicated the fitness of the model. The $\mathrm{R}^{2}$ value of 0.9931 indicated a $99.31 \%$ of combination effect of factors [A] and [B] towards response, while the rest $0.69 \%$ was affected by other unidentified causes. The fitness of the $\mathrm{R}^{2}$ value can be seen from a closer adjusted- $\mathrm{R}^{2}$ value of 0.9963 or $99.63 \%$. The summary model of Totox value response and its analysis of variance are shown in Table 8.

Totox value is in correlation with $\mathrm{PV}$ and $\mathrm{AnV}$ compound; the higher PV and AnV, the bigger Totox value obtained (Hulu et al., 2017). The totox value of a product is gained by summarizing two times PV with $\mathrm{AnV}$. The analysis of variance (ANOVA $\alpha=0.05$ ) result shows that the linear model of factor [A] and factor [B] had given a significant $(\mathrm{p}<0.05)$ effect towards Totox value response with a probability value of 0.0001 . The best explanatory model equation to optimize Totox value response was given as follows:

$$
\mathrm{Y}=57.41372-6.04854 \mathrm{~A}-0.480093 \mathrm{~B}
$$

According to the given equation above it is known that the linear effect of concentration $[\mathrm{A}]$ and time [B] result in a positive effect in minimizing Totox value response. Figure 4 shows the 3D response surface graph of the regression coefficient, which represents the effect of these factors on Totox value response.

\subsection{Bleaching optimization of tuna oil}

\subsubsection{Optimal response conditions}

The suggested bleaching optimization and recommended prediction response by the program can be 


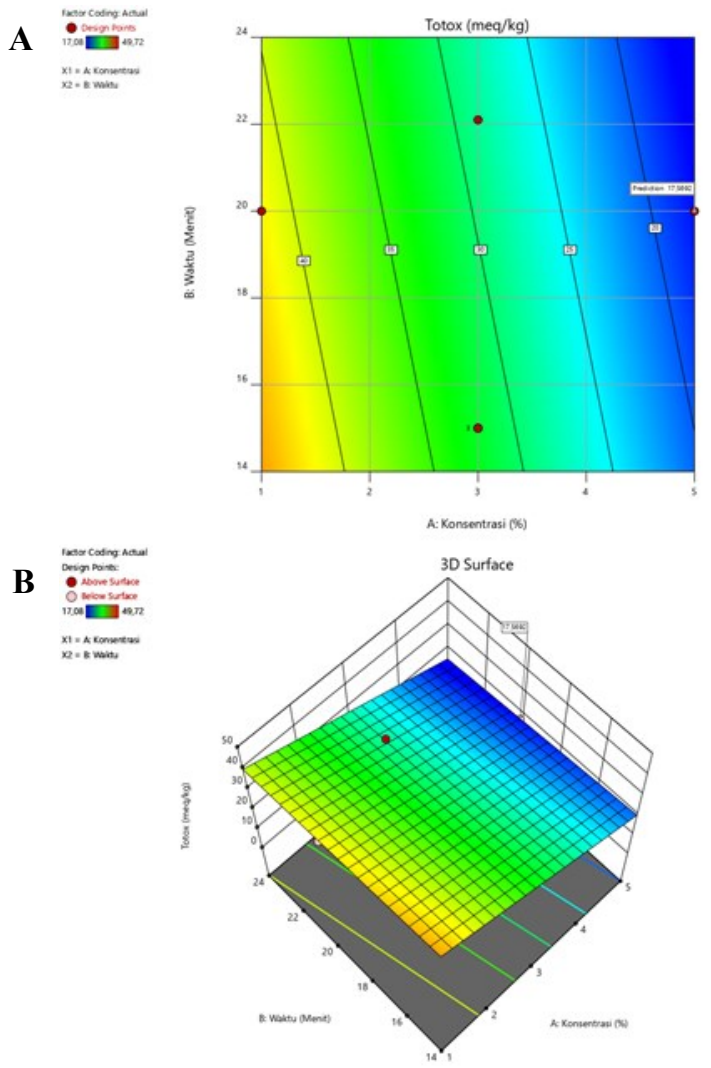

Figure 4. Response surface graph for Totox value (meq $/ \mathrm{kg}$ ) as function of adsorbent concentration $[\mathrm{A}]$ and adsorption time [B]

seen from the following overlay plot (Figure 5). Overlay plot is a technique used to join some responses and variables in the same graph, thus, a conclusion can be made according to the interaction that occurred between responses and variables of each graph. The points chosen in the overlay plot are based on the value of the absorbent concentration and the time of adsorption to decrease the value of FFA, AV, PV, AnV, and Totox (Suseno et al., 2014).

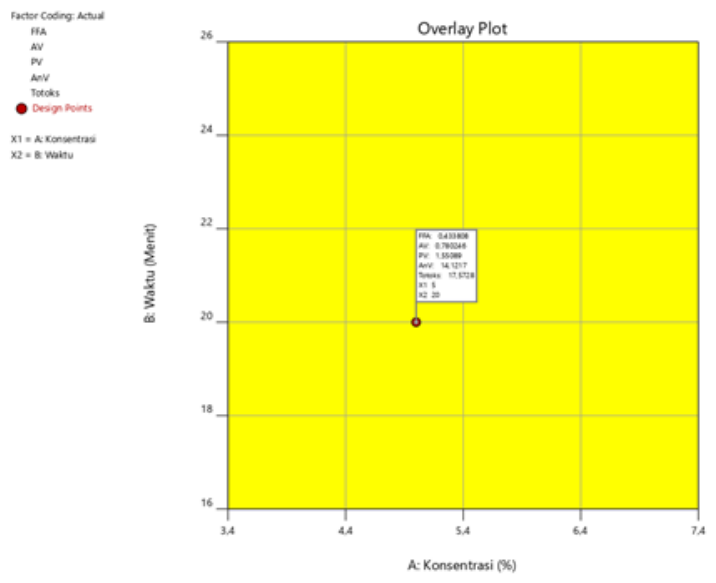

Figure 5. Overlay plot graph

The suggested bleaching conditions for tuna (Thunnus sp.) oil was the adsorbent concentration of $5 \%$ with the adsorption time of 20 mins. The obtained predicted response values were $0.43 \%$ for FFA value, $0.78 \mathrm{mg} \mathrm{KOH} / \mathrm{kg}$ for $\mathrm{AV}, 1.55 \mathrm{meq} / \mathrm{kg}$ for $\mathrm{PV}, 14.12$ $\mathrm{meq} / \mathrm{kg}$ for $\mathrm{AnV}$ and 17.57 for Totox value. The desirability value gained according to the optimum condition process was 0.927 , indicating a $92.7 \%$ of reachability or success probability to be applied in the study. The adsorption process might give better result along with increase concentration [A] and adsorption time [B], however, a study shows that a higher concentration could lead an over adsorption (including natural pigment adsorption) which cause oxidation instability of fish oil. (Saraswati, 2013). The addition of adsorption time increases adsorption capacity until the optimum limit, and the adsorption rate decreases thereafter as can be seen by the model developed for FFA and AnV. This case is related to the saturation point reached at the optimum adsorption time (Setyawati et al., 2015).

\subsubsection{Validation test}

Validation of each response should be done in order to approve the predicted responses generated by RSM. Validation is aimed to observe the fitness between predicted results and actual conditions (Setiawan, 2014). The comparion of the predicted results and the actual condition of fish oil quality parameters is presented in Table 9. The obtained model suggested by the program is considered 'proper' as the predicted values are similar to the actual condition (Madamba, 2005).

Table 9. Comparison of predicted and actual result of each response

\begin{tabular}{lcccc}
\hline \multirow{2}{*}{\multicolumn{1}{c}{ Response }} & & \multicolumn{3}{c}{ Prediction interval } \\
& Actual & Prediction & \multicolumn{2}{c}{$95 \%$} \\
\cline { 3 - 5 } & & & Low & High \\
\hline FFA $(\%)$ & 0.43 & 0.43 & 0.41 & 0.45 \\
AV $(\mathrm{mg} \mathrm{KOH} / \mathrm{g})$ & 0.75 & 0.78 & 0.73 & 0.83 \\
PV $(\mathrm{meq} / \mathrm{kg})$ & 1.62 & 1.55 & 1.03 & 2.07 \\
AnV $(\mathrm{meq} / \mathrm{kg})$ & 14.19 & 14.12 & 13.64 & 14.6 \\
Totox $(\mathrm{meq} / \mathrm{kg})$ & 17.43 & 17.57 & 16.6 & 18.53 \\
\hline
\end{tabular}

The validated results of bleaching optimization were obtained at adsorption concentration [A] of 5\% and adsorption time [B] of 20 mins, where FFA value, AV, $\mathrm{PV}$, AnV and Totox value reached $0.43 \%, 0.75 \mathrm{mg}$ $\mathrm{KOH} / \mathrm{g}, 1.62 \mathrm{meq} / \mathrm{kg}, 14.19 \mathrm{meq} / \mathrm{kg}$ and $17.43 \mathrm{meq} / \mathrm{kg}$, respectively. The actual result for each response lied between the lowest and highest value with a prediction level of $95 \%$, which indicated that the suggested optimization solution is well accepted. Percentage of reduction for each oxidation properties on purified tuna (Thunnus sp.) oil at optimum condition Table 10. The percentage of reduction for each oxidation parameter in this study are in line with a study of sardine oil (adsorbent 5\% and adsorption time 20 mins) which resulted in a reduction of $98.49 \%, 76.58 \%$ and $79.31 \%$ for PV, AnV and Totox value, respectively (Hulu et al., 2017) 
Table 10. Percentage of reduction of oxidation properties on purified tuna (Thunnus sp.) oil

\begin{tabular}{ccccc}
\hline Parameter & Crude oil & Purified oil & Reduction (\%) & Standard \\
\hline FFA value $(\%)$ & $0.99 \pm 0.01$ & $0.43 \pm 0.01$ & 56.57 & $\leq 1.50$ \\
AV (mg KOH $/ \mathrm{g})$ & $1.68 \pm 0.00$ & $0.75 \pm 0.01$ & 55.36 & $\leq 3$ \\
PV $(\mathrm{meq} / \mathrm{kg})$ & $14.54 \pm 0.02$ & $1.62 \pm 0.01$ & 88.86 & $\leq 5.00$ \\
AnV $(\mathrm{meq} / \mathrm{kg})$ & $46.81 \pm 0.24$ & $14.19 \pm 0.02$ & 69.69 & $\leq 20.00$ \\
Totox value $(\mathrm{meq} / \mathrm{kg})$ & $75.89 \pm 0.28$ & $17.43 \pm 0.01$ & 77.03 & $\leq 26.00$ \\
\hline
\end{tabular}

Table 11. Fatty acid profile of purified tuna (Thunnus sp.) oil at optimum condition

\begin{tabular}{|c|c|c|}
\hline \multirow{2}{*}{ Fatty Acid(s) } & \multicolumn{2}{|c|}{ Content $(\% \mathrm{w} / \mathrm{w})$} \\
\hline & Purified oil & Crude oil \\
\hline Lauric acid (C12:0) & 0.03 & 0.04 \\
\hline Tridecanoic acid (C13:0) & 0.03 & 0.02 \\
\hline Miristic acid (C14:0) & 2.55 & 2.20 \\
\hline Pentadecanoic acid (C15:0) & 0.63 & 0.52 \\
\hline Palmitic acid (C16:0) & 15.95 & 13.88 \\
\hline Heptadecanoic acid (C17:0) & 0.50 & 0.43 \\
\hline Stearic acid (C18:0) & 4.72 & 4.06 \\
\hline Arachidic acid (C20:0) & 0.40 & 0.26 \\
\hline Heneikosanoic acid (C21:0) & 0.06 & 0.05 \\
\hline Behenic acid (C22:0) & 0.14 & 0.13 \\
\hline Trikosanoic acid (C23:0) & 0.05 & 0.05 \\
\hline Lignoseric acid (C24:0) & 0.14 & 0.13 \\
\hline Total Saturated Fatty Acid (SFA) & 25.20 & 21.77 \\
\hline Miristoleic acid (C14:1) & 0.05 & 0.04 \\
\hline Palmitoleic acid (C16:1) & 4.36 & 3.94 \\
\hline cis-10- heptadecanoic acid (C17:1) & 0.51 & 0.43 \\
\hline Elaidic acid (C18:1n9t) & 0.16 & 0.14 \\
\hline Oleic acid (C18:1n9c) & 14.97 & 1206 \\
\hline Linolelaidic acid (C18:2n9t) & 0.02 & 12.90 \\
\hline cis-11- eicosanoic acid (C20:1) & 1.91 & 1.65 \\
\hline erukat metil ester (C22:1n9) & 0.29 & 0.26 \\
\hline Nervonic acid (C24:1) & 0.52 & 0.48 \\
\hline Total Mono Unsaturated Fatty Acid (MUFA) & 22.79 & 19.90 \\
\hline Linoleic acid ( C18:2n6c) & 1.60 & 1.40 \\
\hline Linolenic acid (C18:3n3) & 0.57 & 0.50 \\
\hline y- linolenic acid (C18:3n6) & 0.10 & 0.09 \\
\hline cis-11,14- eicosadinoic acid (C20:2) & 0.25 & 0.24 \\
\hline cis-11,14-17-eicosatrienoic metil ester (C20:3n3) & 0.14 & 0.13 \\
\hline cis-8,11,14- eicosantrinoic ( C20:3n6) & 0.14 & 0.13 \\
\hline Arachidonic acid (C20:4n6) & 1.73 & 1.55 \\
\hline cis-5,8,11,14,17- eicosapentaenoic acid (C20:5n3) & 3.08 & 2.75 \\
\hline cis-13,16- docosadinoic acid (C22:2) & 0.02 & 0.04 \\
\hline cis-4,7,10,13,16,19- decosahexaenoic acid (C22:6n3) & 17.92 & 15.86 \\
\hline Total Poly Unsaturated Fatty Acid (PUFA) & 25.55 & 22.69 \\
\hline Total Fatty Acid & 73.54 & 64.35 \\
\hline
\end{tabular}

3.5 Fatty acids profile of purified tuna oil at optimum condition

Gas Chromatography (GC) was also performed in this study in order to identify the fatty acids composition in the sample (Table 11). According to the results, the initial sample contained $21.77 \%$ Saturated Fatty Acid (SFA), 19.90\% Monounsaturated Fatty Acid (MUFA) and $22.69 \%$ Polyunsaturated Fatty Acid (PUFA). The most abundant fatty acid found in SFA, MUFA and PUFA were palmitic acid (13.88\%), oleic acid (12.96\%), and DHA (15.86\%)-EPA (2.75\%), respectively. The EPA and DHA content is usually affected by the feed eaten by the fish such as phytoplankton and zooplankton (Som and Radhakrishman, 2013). The EPA and DHA are highly potential in decreasing cholesterol, cardiac-related -disease, and has an important role in brain and retina growth during pregnancy (Seo and Moujahed, 2015).

Meanwhile, the purified oil contained $25.20 \%$ of saturated fatty acid (SFA), $22.79 \%$ monounsaturated fatty acid (MUFA) and $25.55 \%$ polyunsaturated fatty 
acid (PUFA). The highest fatty acid compound found in the sample was PUFA, including $17.92 \%$ DHA and 3.08\% EPA, which indicated a rising DHA and EPA percentage compared to that unpurified oil as much as $11.50 \%$ for DHA and $10.71 \%$ for EPA. The number of identifiable fatty acids also increased up to $12.50 \%$. Another study revealed that purified tuna oil contained DHA and EPA up to $18.25 \%$ and $12.03 \%$, respectively, with total identified fatty acid up to $67.76 \%$ (Budiadnyani et al., 2015). Purification treatments are able to remove impurities and non-oil compounds along with water compounds on fish oil, this is because the purification process can eliminate impurities and non-oil components, so as to increase the percentage of total fatty acid content in fish oil.

\section{Conclusion}

The reduction of oxidation level including FFA value, $\mathrm{AV}, \mathrm{AnV}, \mathrm{PV}$ and Totox value on tuna oil was significantly affected by the bleaching condition including adsorbent concentration and adsorption time. Based on the suggested model, the optimum conditions were adsorbent concentration of 5\% and adsorption time of 20 mins. The actual values for each response lied between the lowest and the highest value with a prediction level of $95 \%$ indicating that the optimization solution suggested by the program is acceptable. The optimum condition decreased FFA, AV, PV, AnV and Totox value where each value met the IFOS standard.

\section{Conflict of interest}

The authors declare no conflict of interest.

\section{Acknowledgements}

This research is fully supported by funding from the Directorate General of Research Enhancement and Development, Ministry of Research Technology and Higher Education. Republic of Indonesia Penelitian Terapan (No 4308/IT3.1.1/PN/2019) and IPB University through Hibah Program Penelitian Kolaborasi Indonesia (PPKI).

\section{References}

Ahmadi, K. and Mushollaeni, W. (2007). Chemical activation of natural zeolite for purification of fish oil from by-product of fishmeal processing. Jurnal Teknologi Hasil Pertanian, 8(2), 71-79

AOAC (Association of Official Analytical Chemist). (2005). Official Methods of Analysis. $18^{\text {th }}$ ed. Association of Official Analytical Chemists. Arlington, USA: AOAC.

AOCS. (1996). Method Ca 8-53 Peroxide Value Acetic acid-chloroform method. In Official Methods and Recommended Practices of the American Oil Chemists' Society, 2nd ed. Champaign, USA: AOCS Press.

AOCS. (2017a). Method Ca 5a 40 Free Fatty Acids in Crude and Refined Fats and Oils. In Official Methods and Recommended Practices of the American Oil Chemists' Society. 6th ed. Champaign, USA: AOCS Press.

AOCS. (2017b). Method Ca 18-90 p-Anisidine Value. In Official Methods and Recommended Practices of the American Oil Chemists' Society. 6th ed. Champaign, USA: AOCS Press.

Budiadnyani, I.G.A. (2017). Pengaruh jenis dan konsentrasi adsorben terhadap karakteristik fisikokimia minyak ikan dari hasil samping industri pengalengan tuna madidihang (Thunus albacores). Technology Science and Engineering Journal, 1(2), 119-127. [In Bahasa Indonesia].

Budiadnyani, I.G.A., Estiasih, T. and Yunianta. (2015). Characteristics and fatty acid profile of refined fish oil from by-product of yellowfin tuna (Thunnus albacares) meal processing. Journal of Life Science and Biomedicine, 5(5), 132-136.

Codex Alimentarius Commision. (2017). Standard for Fish Oils Codex Stan 329-2017. Retrieved from Codex Alimentarius Commission website: https:// www.iffo.net/system/files/Codex\%20Standard\% 20 for $\% 20$ Fish $\% 20$ Oils $\% 20$ CXS 329e Nov\% 202017.pdf

Crexi, V.T., Grunennvaldt, F.L., de Souza Soarez, L.A. and Pinto, L.A.A. (2009). Deodorisation process variable for croaker (M. furnieri) oil. Food Chemistry, 114(2), 369-401. https://doi.org/10.1016/ j.foodchem.2008.09.032

Dari, D.W., Astawan, M., Wulandari, N. and Suseno, S.H. (2017). Characteristics of sardin fish oil (Sardinella sp.) resulted from stratified purification. Jurnal Pengolahan Hasil Perikanan Indonesia, 20 (3), 456-467. https://doi.org/10.17844/ jphpi.v20i3.19766

Estiasih, T. (2009). Minyak Ikan Teknologi dan Penerapannya untuk Pangan dan Kesehatan. Yogyakarta, Indonesia: Graha Ilmu. [In Bahasa Indonesia].

Feryana, I.W.K., Suseno, S.H. and Nurjanah. (2014). Refining of mackerel fish oil from fish meal processing byproduct with alkali neutralization. Jurnal Pengolahan Hasil Perikanan Indonesia, 17 (3), 208-214. https://doi.org/10.17844/ jphpi.v17i3.8907

Hodgum, A.S. (1995). Refining and Bleaching: In Hui, 
Y.H. (Ed.). Bailey's Industrial Oil and Fat Products. Edible Oil and Fat Products: Processing Technology. New York, USA: John Wiley and Sons Inc.

Huli, L.O., Suseno, S.H. and Santoso, J. (2014). Fish oil quality of by-product (fish skin) from swangi fish. Jurnal Pengolahan Hasil Perikanan Indonesia, 17 (3), 233-242. https://doi.org/10.17844/ jphpi.v17i3.8912

Hulu, D.P.C., Suseno, S.H. and Uju. (2017). Improving the Quality of Sardine Fish Oil by Degumming Using Sodium Cholride Solution. Jurnal Pengolahan Hasil Perikanan Indonesia, 20(1), 199-210. https:// doi.org/10.17844/jphpi.v20i1.16508

Ketaren, S. (2012). Pengantar Teknologi Minyak dan Lemak Pangan. Depok, Indonesia: UI Press. [In Bahasa Indonesia].

Khotimah, K., Darius and Sasmito, B.B. (2013). Uji Aktivitas Senyawa Aktif Alga Coklat (Sargassum fillipendulla) sebagai Antioksidan pada Minyak Ikan Lemuru (Sardinella longiceps). THPi Student Journal, 1(1), 10-20. [In Bahasa Indonesia].

Kusnandar, F. (2010). Kimia Pangan: Komponen Makro. Jakarta, Indonesia: PT Dian Rakyat. [In Bahasa Indoensia].

Madamba, P.S. and Yabes, R.P. (2005). Determination of Optimum Intermittent Drying Condition for Rough Rice (Oryza sativa L). LWT - Food Science and Technology, 38(2), 157-165. https:// doi.org/10.1016/j.lwt.2004.04.018

Ministry of Marine Affairs and Fisheries. (2018). Indonesian Fisheries Productivity. Jakarta, Indonesia: Ministry of Fisheries and Marine Affairs, Republic of Indonesia.

Mohanarangan, A.B. (2012). Extraction of omega-3 fatty acids from Atlantic Herring (Clupea herengus). Canada: Dalhousie University, Thesis.

Montgomery, D.C. (2005). Design and Analysis of Experiments. 5th ed. New Jersey, USA: John Wiley and Sons. Inc.

Nadjib, N.A. (2016). Optimasi proses pembuatan biopelet dari ampas kopi instan dan arang tempurung kelapa dengan response surface method. Bogor, Indonesia: Bogor Agricultural University, Thesis. [In Bahasa Indonesia].

Nurnafisah, I. (2016). Optimasi pemurniaan minyak ikan lemuru (Sardinella sp.) hasil netralisasi menggunakan metode permukaan respon. Bogor, Indonesia: Bogor Agricultural University, Thesis. [In Bahasa Indonesia].

Panagan, A.T., Yohandini, H. and Gultom, J.U. (2011). Analisis Kualitatif dan Kuantitatif Asam Lemak Tak Jenuh Omega-3 dari Minyak Ikan Patin (Pangasius pangasius) dengan Metode Kromatografi Gas. Jurnal Penelitian Sains, 14(4C), 38-42.

Puspitojati, E. and Santoso, H. (2012). Optimasi Fementasi pada Pembuatan Ekstrak Temulawak sebagai Bahan Baku Es Krim. Jurnal Ilmu Pertanian, 16(2), 91-99. [In Bahasa Indonesia].

Ristianingsih, Y., Sutijan and Arif, B. (2011). Kinetic study of chemical and physical degumming of crude palm oil (CPO) using phosphoric acid. Reaktor, 13 (4), 242-247.

Saraswati. (2013). Pemurnian minyak ikan lemuru (Sardinella lemuru) menggunakan sentrifugasi dan adsorben bentonit. Bogor, Indonesia: Bogor Agricultural University, Thesis. [In Bahasa Indonesia].

Sari, R.N., Utomo, B.S.B., Basmal, J. and Kasumawati, R. (2015). Optimization of fish oil sardinella lemuru from canning industry by products. Jurnal Pengolahan Hasil Perikanan Indonesia, 18(3), 276286. https://doi.org/10.17844/jphpi.v18i3.11279

Sarma, A.D., Mallick, A.R. and Ghosh, K. (2010). Free radicals and their role in different clinical conditions: An overview. International Journal of Pharma Sciences and Research, 1(3), 185-192.

Sathivel, S. and Prinyawiwatkul, W. (2004). Adsorption of FFA in crude catfish oil onto chitosan, activated carbon, and activated earth: A Kinetics Study. Journal of the American Oil Chemists' Society, 81 (5), 493-496. https://doi.org/10.1007/s11746-0040929-0

Seo, G. and Moujahed N. (2015). Seasonal variation of chemical and fatty acids composition in atlantic mackerel from the Tunisian Northern-East Coast. Journal of Food Processing and Technology, 6(9), 24. https://doi.org/10.4172/2157-7110.1000487

Setiawan, F. (2014). Optimasi proses produksi papan partikel dari ampas biji jarak pagar (Jatropha curcas L.) menggunakan response surface method (RSM). Bogor, Indonesia: Bogor Agricultural University, Thesis. [In Bahasa Indonesia].

Setyawati, H., Rakhman, N.A. and Anggorowati, D.A. (2015). Penerapan Penggunaan Arang Aktif Sebagai Adsorben untuk Proses Adsorpsi Limbah Cair di Sentra Industri Tahu Kota Malang. Spectra, 26(13), 67-78. [In Bahasa Indonesia].

Som, R.S.C. and Radhakrishman, C.K. (2013). Seasonal Variation in The Fatty Acid Composition of Sardinella longiceps and Sardinella fimbriata: Implication for Nutrients and Pharmaceutical Industry. Indian Journal of Marine Science, 42(2), 206-210.

Suparno, I.A.K and Muchlis. (2013). Sains dan 
Teknologi Proses Produksi Minyak/Lemak dan Kulit Samoa (Chamois Leather). Bogor: IPB Press. [In Bahasa Indonesia].

Suseno, S.H., Batafor, Y.M.J., Nurjanah and Izaki, A.F. (2014). Improved quality of sardine oil (Sardinella sp.) using passive filter (centrifugation). Advance Journal of Food Science and Technology, 6(5), 609615. https://doi.org/10.19026/ajfst.6.83

Suseno, S.H., Musbah, M. and Ruspati, N.M. (2016). Karakteristik minyak ikan murni sardin (Sardinella sp.) dan cucut (Centrophorus sp.) sebagai bahan suplemen makanan kaya omega-3 dan squalen. Prosiding Seminar Nasional Kelautan. Madura, Indonesia: Universitas Trunojoyo. [In Bahasa Indonesia].

Suseno, S.H., Nurjanah and Faradiba, T. (2013). Characterization and stabilization of product formulation of fish and Habbatus sauda oil. Jurnal Pengolahan Hasil Perikanan Indonesia, 16(2), 142149.

Suseno, S.H., Tajul, A.Y., Nadiah, W.A. and Noor, A.F. (2012). Improved of color properties on Sardinella lemuru oil during adsorbent refining using magnesol X1. International Food Research Journal, 19(4), 1383-1386.

Syakiroh, N.M. (2012). Peningkatan kualitas asam lemak bebas omega-3 minyak ikan limbah pengalengan ikan melalui proses degumming, netralisasi, dan bleaching dengan karbon aktif biji kelor (Moringa oleifera Lamk) teraktivasi $\mathrm{NaCl}$. Malang, Indonesia: Universitas Islam Negeri Maulana Malik Ibrahim, Thesis. [In Bahasa Indonesia].

Tambunan, J.E., Suseno, S.H. and Ibrahim, B. (2013). Improved Quality of Sardines Oil (Sardinella $s p$.) Using Centrifugation. Global Journal of Biology. Agriculture and Health Sciences, 2(4), 196-202.

Wardhani, A.P. (2012). Optimasi Kristalisasi Pelarut Suhu Rendah Pada Proses Pembuatan Konsentrat Asam Lemak $\Omega-3$ Dari Minyak Hasil Samping Pengalengan Ikan Tuna (Thunnus sp.). Malang, Indonesia: Universitas Islam Negeri Maulana Malik Ibrahim, Thesis. [In Bahasa Indonesia].

Zuta, P.C., Simpson, B.K., Zhao, X. and Leclerc, L. (2007). The Effect of $\alpha$-tochopherol on the Oxidation of Mackerel Oil. Food Chemistry, 100(2), 800-807. https://doi.org/10.1016/j.foodchem.2005.11.003 